\title{
THE PLACE AND THE ROLE OF SPORT IN THE WAR-TORN SOCIETY OF AFGHANISTAN
}

\author{
Ivanka Martinova \\ CPE "Terra" at Inovationtech Ltd (Bulgaria). \\ Muammer Aydin \\ National Sports Academy "Vassil Levski" (Bulgaria)
}

\begin{abstract}
For Afghanistan, security is one of the last things the country can be associated with. Despite the efforts that have been made over the last decade, it is still too early to speak about political, economic, and institutional stability. Against this background of uncertainty, and despite the lack of legislation, funding, and investment tools, Afghanistan's flag is being played in the finals of many international events. This is the phenomenon that provokes our research interest. The present aims to give a brief overview of the country's national sporting achievements and to examine the views of two key experts in the field to identify how the development of sport in the country influences the peace-making processes from a social perspective. The used methodology includes a semi-structured interview conducted independently with both respondents in 2019 which is analyzed in the context of social reconstruction of a war-torn society. The results show that national success in elite international sports events has a high potential to be an effective tool in neutralizing some of the negative social effects of war on the society (like distancing, hatred, identity restructuring, etc.) by bringing hope, creating role models, changing perceptions, uniting people under one flag, creating heroes.

Keywords: social reconstruction; national identity; peacebuilding; sport success
\end{abstract}

\section{Introduction}

Western sports (tennis and golf) get popular in Afghanistan in the XX century during the reign of Amir Habibullah (Qazi Abdullah 2018). In 1922 is established the first Afghan football club and a year later was built the first stadium in Kabul Ghazi Stadium. During the Taliban regime (1996 - 2001), the sport is very limited and no action is taken to develop or stimulate it. In this period, in which the laws of sharia are strictly applied, women are absolutely forbidden to attend major events, to leave their homes unaccompanied, and their sports participation is strictly prohibited (Afghan women break new ground through sport 2013). Some of the very few sports that are tolerated during the regime are football and cricket (Toohey 
\& Taylor 2006) but even this only entertainment for society was often preceded by horror. As a general practice, an hour before a sporting event the spectators were invited to the stadium to watch live the executions carried out as a punishment for non-compliance with the rules of the regime. Only after that, the sports matches can begin. (Giulianotti \& Armstrong 2011; Kabul Moncho Torres 2019).

What is impressive about the case of Afghanistan is that despite all the repressions during the regime, the lack of sports infrastructure, and the limitations in terms of sports organization and administration, the Afghan athletes demonstrate amazing success in various sports. One of them is cricket which became more popular in 2002 when the Afghan refugees in Pakistan returned to their country (Afghanistan Sports and Traditional Games, no date). In November 2007, Afghanistan and Oman hosted together the Asian Cricket Council Cup, an event in which 10 Asian countries took part, among which Afghanistan, won the elite trophy. In 2008, Afghanistan took part in the World Cricket League. In 2009 the national team played in the ICC World Cup qualification and for the first time got qualified in the first division in 2010 at the 20 ICC World Championships. (Live Cricket Scores \& News - ICC T20 World Cup 2020 n.d.). In May 2017, the International Cricket Council awarded status A to the one-day regional competition Ghazi Amanullah Khan, the 4-day competition Ahmad Shah Abdali, and the Twenty20 Shpageeza Cricket League, which made possible for the Cricket Board of the country to announce in 2018 the first Afghan Premier League (an annual T20 domestic league). Currently, there are 320 registered cricket clubs.

The 2008 Summer Olympics were a special event for the country when Afghanistan won its first Olympic medal. The pride of the bronze was brought by the national taekwondo athlete Nohullah Nikpai who re-confirmed the success with the bronze medal at the 2012 Olympics. Since this success, this martial art became extremely popular in the country. Another martial art which becomes well spread and practiced in the country is Muay Thai. At the Asian Open Muay Thai Championship in Tashkent in 2010, Afghanistan was represented by 16 athletes and ended with one gold and eight bronze medals.

The modern success story of Afghan football began with the SAFF Championship in 2011 when Afghanistan marked its first international victory over Nepal. In the same year, the national team won the FIFA Fair Play Award. In 2013, the country won the football championship of the South Asian Football Federation.

Another well-established sport discipline in Afghanistan is bodybuilding which seems to be also tolerated during the years of the Taliban regime (Bodybuilding: The pursuit of beauty in war-torn Kabul, 2018). In 2017, Afghans won gold, silver, and bronze medals at the World Bodybuilding Championships, where Ahmad Yassin glorified his country, winning the title "Mr. Universe" (World Bodybuilding and Physique Sports Federation 2019). In 2018, Yasin Salik Qaderi managed to win a gold medal at the Global Classic bodybuilding competition in Macau, China 
(Afghanistan's Yasin Qaderi wins Gold Medal in Macau bodybuilding competition 2018). Afghan athletes also managed to win 6 gold, two silver, and three bronze medals at the $12^{\text {th }}$ Bodybuilding Championship of South Asia in 2019 in Nepal (Afghan Bodybuilders Win South Asian Bodybuilding Title 2019).

What makes these and many more success stories like them so impressive is that their cradle is far from what the textbooks say it should be. The phoenix of the Afghan international sport success rises from the ashes of the Taliban regime and its severe restrictions on sports and sports participation; of the long years of still ongoing war conflict, hostilities, serious security threats, lack of sports experts, coaches, and appropriate conditions. At first sight, putting emphasis on sports development in a time of living physical threat and many unsolved economical and social problems might seem like an immature idea. A deeper look into the topic shows us that namely, the success of the elite sport is what has the real potential to promote the social reconstruction process of the war-torn society, solving issues connected to the harmful socio-psychological effects of war such as national identity.

\section{Aim}

The present article aims to study the contemporary sport's success in Afghanistan and to examine their social importance on the local society in the process of peacebuilding.

\section{Methodology}

To satisfy the need for up-to-date information about the present condition of the research problem we conduct a semi-structured interview (Adams 2015) with specialists who are considered to have a professional look at the development of the Afghan sport.

For the present study were interviewed:

1) Dr. Mohammad Yonus Popalzay - General Secretary of the National Olympic Committee of Afghanistan.

2) Mr. Sayed Sharaf Amiri - General Secretary of the University Sports Federation of Afghanistan (UFSA).

The questions of the interview are developed based on the results of a larger literature review. The respondents are asked several questions which aim to examine: personal observations on the effects of war on the Afghan society; the place and the effects of the sport in the Afghan society; the media coverage of the sports events; personal observations on the way the national sport's success affects the sport participation of the population.

The interviews were conducted in the beginning and middle of 2019. With the permission of the interviewees, the interviews were recorded. Both interviews were conducted independently, orally, in English. 
After each interview, the recordings were transferred into text format. The answers to the questions were coded by keywords. Particular attention was paid to words and expressions that were: repeated by the respondent, words, and expressions that the interviewee himself mentioned as "particularly important fact", as well as words and expressions that were used in both interviews.

In the analysis, the interviews were compared to be identified: common points of view of the two independent interviewees; points of supplementing the information; points of contradiction; new information, which so far has not been found in the theoretical study but is important from an analytical point of view to explain the observed phenomena.

\section{Results and discussion}

War conflicts can create severe long-term damage to the mental health of both soldiers and civil population. Apart from the special mental training that the professional soldiers receive, a study of Iancheva, Domuschieva-Rogleva and Kuleva (2018) reveals that for professional military personnel served in Afghanistan there are found specific coping strategies as well as personal peculiarities connected to sensation seeking, impulsivity and other personal traits. The special military preparation and the specific personal traits are the reason why we suppose that the effects of war conflicts on soldiers and civil society would be different and thus for the present article are examined only the effects on the Afghan society without particular focus on the military personnel. The most common effects of war on civil society are connected to fear, post-traumatic stress, desire for revenge, identity restructuring, anxiety, hatred, feelings of betrayal, ethnic prejudice, etc.(McAfee 1997; Centers for Disease Control and Prevention 1999; Woodside, Santa Barbara, and Benner 1999; Kaminer et al. 2001; Summerfield 2002; Turton 2002; Cardozo et al. 2004; Kashdan, Morina and Priebe 2009). To confirm whether these effects can also be found in Afghan society, we are asking about the observed effects of the war on the people of Afghanistan.

Given the specifics of the topic and the risk of losing some of the interviewees' messages in the analysis, we try to keep as much as possible relevant text of the answers. Repetitive, different, complementary, or contradictory statements will be bolded in the original text and analyzed after it.

Table 1. Interview: the effects of war on the Afghan society

\begin{tabular}{|c|c|}
\hline Dr. Mohammad Yunus Popalzay (NOC) & Mr. Sayed Saraf Amiri (USFA) \\
\hline $\begin{array}{l}\text { Uncertainty is of kinds of insecurity } \\
\text { observed - physical and mental. The } \\
\text { mental leads to distancing people, } \\
\text { reducing their sociability to protect } \\
\text { themselves, lack of trust, anger, hatred. }\end{array}$ & $\begin{array}{l}\text { At a recent wedding, there was an explosion } \\
\text { that killed seven members of a family. Such } \\
\text { events discourage people from qathering } \\
\text { or meeting, going out, or surrounding } \\
\text { themselves with their families. }\end{array}$ \\
\hline
\end{tabular}


They do not feel protected when they are together, they feel safe when they are at distance from each other. One of the biggest effects is regarding trust. SO they do not trust each other. Distance between people is one of the most serious effects of war, human rights are violated and they do not believe in the state and its institutions. People become more egocentric and in their quest to protect themselves, they less and less strive for the good of the other - reduced sense of humanity and friendship.
This is a common feeling in Afghanistan. We are afraid to go out, we are afraid to attend events where a lot of people gather. We are afraid to go out during the holidays and spend our free time in public places... 3 months ago we had to travel to Italy because of our work on university sports. On the same day, there was an explosion in the NOC building and some of our colleagues were injured and some died. Such things have a negative effect on our society.

Both interviews confirm the common feeling of fear as an effect of insecurity. This insecurity and the continuous attacks distance the people and discourage them to take part in any public events. The answer of Dr. Popalzay confirms the effects of war reported in other studies, namely anger, hatred, mistrust which demonstrates how the social and mental health of the Afghan population is negatively affected by the armed conflicts. From the answers to this first question, we can identify one of the key aspects on which the respective authorities should take measures if they want to foster mass sports participation - good physical security.

But if the mass events recall unpleasant feelings, then it is interesting to understand what is the present place of sport in Afghan society.

Table 2. Interview: the place of sport in the Afghan society and the effects of the sport on it

\begin{tabular}{|c|c|}
\hline Dr. Mohammad Yunus Popalzay (NOC) & $\begin{array}{c}\text { Mr. Sayed Saraf } \\
\text { Amiri (USFA) }\end{array}$ \\
\hline $\begin{array}{l}\text { Sport is the only factor that unites people and makes them } \\
\text { feel happy. Examples are the successes in football, volleyball, } \\
\text { cricket, taekwondo. } \\
\text { When Afghanistan became the champion of Southeast Asia } \\
\text { in } 2016 \text {, everyone was crying out of happiness. Sport unites } \\
\text { them regardless of their religion, language, and geographical } \\
\text { location. At this moment, everyone is an Afghan crying } \\
\text { because of his team's victory. When Rohullah Nikpai became } \\
\text { a bronze medalist in taekwondo at the } 2008 \text { Olympics, everyone } \\
\text { was dancing and rejoicing. He brought pride to the nation } \\
\text { which celebrated this occasion. This year, the national team of } \\
\text { Afghanistan is competing in the World Cricket Championship } \\
\text { and this makes the whole nation excited and praying for } \\
\text { them. We believe that at this stage, sport is the only thing that } \\
\text { unites people in Afghanistan and has the potential to change }\end{array}$ & $\begin{array}{l}\text { Today the sport } \\
\text { in Afghanistan is } \\
\text { developing very fast } \\
\text { and I can confirm the } \\
\text { enthusiasm of the } \\
\text { Afghan youth to } \\
\text { play sport. This is } \\
\text { observed especially } \\
\text { for individual sports. } \\
\text { We do not have a } \\
\text { choice. Regardless of } \\
\text { the fact whether there } \\
\text { is an explosion, a war, } \\
\text { or a Taliban attack, we } \\
\text { have to continue. }\end{array}$ \\
\hline
\end{tabular}




\begin{tabular}{|c|c|}
\hline Dr. Mohammad Yunus Popalzay (NOC) & $\begin{array}{c}\text { Mr. Sayed Saraf } \\
\text { Amiri (USFA) }\end{array}$ \\
\hline $\begin{array}{l}\text { are full of bombs, military action, suicide attacks, or other terrorist } \\
\text { acts, the only positive news is the sports news. The Olympic } \\
\text { movement has played a major role, especially since } 2001 \text {, but } \\
\text { before that, the idea was suppressed by the Taliban regime. } \\
\text { Our observations are that when children play together, they } \\
\text { forget all the bad things that happened yesterday, all the } \\
\text { traumatic experiences that have an effect on them because } \\
\text { of the war. } \\
\text { Sport creates role models for the young people. For example, } \\
\text { Rohullah Nikpai was a man who was completely unknown to } \\
\text { anyone, but when the Olympic Committee supported him and } \\
\text { gave him the opportunity to compete internationally, he is now } \\
\text { an adviser on the sports issues to Afghanistan's second vice } \\
\text { president. We believe that sport is a powerful tool that can } \\
\text { change people's thinking and unite them, building positivity, } \\
\text { friendship. }\end{array}$ & $\begin{array}{l}\text { Our people do not } \\
\text { lose hope, they are } \\
\text { very keen on sport. } \\
\text { I wish I could say } \\
\text { that the war did not } \\
\text { influence sport but } \\
\text { definitely it has an } \\
\text { effect on it because it } \\
\text { suppressed the strive } \\
\text { of the people to go } \\
\text { out and participate in } \\
\text { events. But we do not } \\
\text { have a choice. Our } \\
\text { youth continues to do } \\
\text { sports passionately } \\
\text { and to make its best } \\
\text { to reach results. } \\
\end{array}$ \\
\hline
\end{tabular}

Several times Dr. Popalzay says that sport is "the only factor which unites the people", "the only good news on the TV", "the only thing which has the potential to change the way of thinking". Considering the heterogenous ethnical structure of the Afghan society, the words of the General Secretary of the National Olympic Committee that during the sports events "everyone is an Afghan" sound extremely powerful. This statement is an important key to a direction for further work and development because namely identity problems are one of the most pressing issues which have to be considered in the process of social reconstruction of war-torn societies. Dr. Popalzay considers sport as a tool through which the effects of war on the children can be decreased. A new element in the analysis which was not found in the theoretical review on the topic is the power of sports to create role models. An inspiring example of transformation through sport is the personal story of Rohullah Nikpai who from a completely unknown person turns to be an international star who occupies a highly responsible and respected position in the state. On the other hand, in the response of Mr. Amiri to the same question, we see that two statements are repeated several times - "keen/passion" and "we do not have a choice". These phrases emphasize sport as a passion which encourages those who practice it to continue doing it denying the fear and obedience as optional choices. Sport here is a form of empowerment.

The obvious negative effects of the war on one hand, and the proven positive effects of sports on the other, justify the use of sport as a tool in the process of "healing" of a war-torn society. Traditionally, media has a considerable effect on shaping people's mindset and this becomes our motivation to study the place of sport in the media in Afghanistan. 
Table 3. Interview: Media coverage of sports in Afghanistan

\begin{tabular}{|c|c|}
\hline Dr. Mohammad Yunus Popalzay (NOC) & Mr. Sayed Saraf Amiri (USFA) \\
\hline $\begin{array}{l}\text { Together with sports, Afghanistan made great strides } \\
\text { in media, media freedom, and media reach to the } \\
\text { people. Sports have always been close to the } \\
\text { media. Those role models, sports heroes, and } \\
\text { champions have always been presented in the } \\
\text { media. We have more than } 40 \text { TV channels and } \\
\text { more than } 170 \text { radio channels. I can assure you that } \\
\text { every radio and TV broadcast sports every day and } \\
\text { follow those people who become a reason for pride } \\
\text { during the competitions. They are broadcasted every } \\
\text { morning. There are several very famous TV channels } \\
\text { like TolaTV, Arayanot TV, and Shamshad TV. More } \\
\text { than } 20 \% \text { of their program is a live sport. Now there } \\
\text { is another channel -3Sport which broadcasts sport } 24 \\
\text { hours. Regarding the radio, there is another channel } \\
\text { "Azadi" which is connected to the "Voice of America" } \\
\text { which is also the most famous radio. Every Tuesday } \\
\text { they broadcast a 3-hours show dedicated only to } \\
\text { the sport. Also, we as NOC every week make a press } \\
\text { release and update our Twitter and Facebook as well } \\
\text { as our website which is still under construction. These } \\
\text { are mostly the instruments which are used and the } \\
\text { people are always happy to see such programs; } \\
\text { people are always happy to see their heroes, the } \\
\text { people who bring pride. All the TV channels are } \\
\text { private except for one and they are commercially } \\
\text { oriented. They have their own strategies. For } \\
\text { example, ToloTV has a strategy for sport. Every } \\
\text { Saturday they broadcast a two-hours show } \\
\text { dedicated to the Martial Arts and they invite athletes } \\
\text { from foreign countries - Iran, Tajikistan, Russia, to } \\
\text { compete with Afghans. This is very good but for them, } \\
\text { this is a strategy to bring more profits and attract more } \\
\text { sponsors and advertisers. On the national TV and } \\
\text { on national level unfortunately there is no strategy } \\
\text { for sports broadcasting but this is an interesting } \\
\text { point which I will direct to our president to present it } \\
\text { to the Ministry of Communications which controls and } \\
\text { monitors all the media. }\end{array}$ & $\begin{array}{l}\text { The TV's and the radios } \\
\text { broadcast the big sports events. } \\
\text { Many people watch sports and } \\
\text { follow sports. For example, } \\
\text { in a few days, there will be a } \\
\text { Martial Art competition between } \\
\text { an Athlete from Afghanistan } \\
\text { and his opponent from Russia. } \\
\text { There is more than a week to } \\
\text { the match but the people are } \\
\text { already researching, they are } \\
\text { thirsty to watch more. I told } \\
\text { you, the sports events have } \\
\text { a very positive impact on } \\
\text { the people. And when our } \\
\text { athletes go abroad to present } \\
\text { Afghanistan, this aims to show } \\
\text { the world that the Afghans are } \\
\text { not terrorists; this has a very } \\
\text { positive message to the other } \\
\text { countries. This is the reason } \\
\text { why our people are excited and } \\
\text { follow the events. } \\
\text { In Afghanistan, there is only one } \\
\text { sports TV channel - 3Sport but } \\
\text { the other TV's also broadcast } \\
\text { sports. For example, Roshan, } \\
\text { the Prime League of Afghanistan } \\
\text { is broadcasted live on one of the } \\
\text { biggest TV channels - TolaTV. } \\
\text { The smaller events or local } \\
\text { events are broadcasted on } \\
\text { 3Sport where are broadcasted } \\
\text { many other sports events } \\
\text { - national, international, } \\
\text { championships, Olympic } \\
\text { Games, World Cups, etc. }\end{array}$ \\
\hline
\end{tabular}

From the answer of Dr. Popalzay, we get very detailed information about the connection between media and sport in Afghanistan which is very typical for the global development of the Olympic movement. As Vladova (2018) says, the Olympic games nowadays are "a factor of global importance" and attract not only the interest of athletes and trainers but also the interest of millions of TV viewers and the media respectively 
(Vladova 2018). Accordingly, sports shows are an important element from the program of every media in Afghanistan. From the social point of view, "people are always happy to watch such programs", "people like to see their heroes who bring them happiness", which is the reason for the media to start developing their strategies more and more considering the idea of broadcasting more sports which will guarantee them a good rating and profits, respectively. This symbiosis assures a sustainable mechanism that secures the place of sport among the society and maintains levels of joy and national pride. Here we see another aspect of the importance of international sports events. They become a tribune for the Afghan people from which through their athletes they send their message for peace and declare their desire to show another face of their country and nation.

The last question to the interviewees aims to get more information about the public response to sports success and whether the international achievements of the national teams manage to provoke the interest of the people in sport and increase the number of sport participants.

Table 4. Interview: the way the national sports achievements influence the sport participation of the people of Afghanistan

\begin{tabular}{|c|c|}
\hline Dr. Mohammad Yunus Popalzay (NOC) & Mr. Sayed Saraf Amiri (USFA) \\
\hline $\begin{array}{l}\text { Increasing the number of people doing sports is } \\
\text { one of the success factors in sport. Let me give an } \\
\text { example. We are working to increase the number of } \\
\text { women in sports. Robina Jalali is the first woman to } \\
\text { compete in the Olympics, representing Afghanistan } \\
\text { in } 2004 \text {. She is now a member of parliament and is } \\
\text { becoming a very good role model for other girls. I see } \\
\text { the reactions of the girls who come to play volleyball } \\
\text { or football after school. They all see Robina as an } \\
\text { example of a good person, a successful athlete, and a } \\
\text { politician. There are also other female athletes who are } \\
\text { not as prominent as medalists, but they bring pride to } \\
\text { the country and have become an example in a way } \\
\text { that families have begun to allow their daughters to } \\
\text { do sports. Families are beginning to realize that their } \\
\text { sons and daughters can bring pride not only to } \\
\text { Afghanistan but to their families. } \\
\text { If someone is a professional cricket or football player, } \\
\text { you can hear on the streets "Oh, look, this is Hamid } \\
\text { Asan's father". This way of thinking is already } \\
\text { here and it helps a lot. Now we plan to organize } \\
\text { national Afghan games because we believe that they } \\
\text { legitimize the sport. More than } 500 \text { people will take } \\
\text { part in this national competition and more than } 100 \\
\text { medals will be awarded. It is also a kind of strategy with } \\
\text { which we want to make people encourage their children } \\
\text { to play sports. }\end{array}$ & $\begin{array}{l}\text { Yes, people start playing } \\
\text { more sports after seeing } \\
\text { the national success. On } \\
\text { one hand, this is not just } \\
\text { in Afghanistan. This is a } \\
\text { phenomenon all over the } \\
\text { world, which is also observed } \\
\text { in our country. After the first } \\
\text { cricket team was formed and } \\
\text { its success followed, more } \\
\text { and more people started } \\
\text { playing cricket. Also, free } \\
\text { fights are now very fashionable } \\
\text { in Afghanistan. Several } \\
\text { athletes have become heroes } \\
\text { of Afghanistan after their } \\
\text { international victories. And we } \\
\text { notice that when something } \\
\text { good happens, people start } \\
\text { doing it because people } \\
\text { are very likely to continue } \\
\text { something good. } \\
\text { When our athletes win a medal } \\
\text { in an international competition, } \\
\text { people gather to welcome them } \\
\text { and celebrate with them. }\end{array}$ \\
\hline
\end{tabular}


The answers of the respondents lead us to the conclusion that greater success in the elite sport would have a significant impact on the sports participation of the other citizens, because "people are likely to continue something good". Here we observe how the cultural value of family honor is successfully used by the National Olympic Committee to change the perceptions towards sport. While during the Taliban regime, the sportswoman was a disgrace to the family, today, professional sports events bring honor to the family and more and more families encourage their children to participate in sports. It is worth noting an expression that appears relatively often when it comes to professional athletes, namely - "heroes". This word encodes the whole meaning of Afghanistan's attitude towards sport and its potential to contribute to the process of social reconstruction. The creation of a national hero is one of the first steps in the unification of a nation, and this process began to occur and develop naturally in Afghanistan.

This gives us reason to believe that intentional actions in this direction would be highly effective and would support the peace-building process in this war-torn society.

\section{Conclusion}

The review of the current international successes of the Afghan sport and the results of the interview with the two respondents give us the reason to believe that the development of sports and especially the development of elite sports can be a key element in raising national self-confidence, bringing up national pride and achieving domestic peace in a post-war society. National athletes are described as "heroes". In the moments of international competitions, the people forget the ethnic and family quarrels and everyone shares the joy under one flag. Here is the place to recall Mr. Amiri's words about the importance of elite sports as a platform for international interaction, namely, "Our people want peace. Afghanistan is not just terrorists. Sport is the only way we can send our message of peace to all other nations".

\section{REFERENCES}

Adams, W., 2015 Conducting Semi-Structured Interviews, in Jossey-Bass, Editors: J. Wholey, H.Hatry, K. Newcomer (Eds.), Handbook of Practical Program Evaluation (4) doi: 10.1002/9781119171386.ch19.

Afghan women break new ground through sport (2013) UNAMA. Available at: https://unama.unmissions.org/afghan-women-break-new-groundthrough-sport. Accessed: 1 October 2019.

Afghanistan Sports and Traditional Games (no date). Available at: http:// www.afghanistan-culture.com/afghanistan-sports.html. Accessed: 15 October 2019. 
Cardozo, B. L. et al., 2004. Mental health, social functioning, and disability in postwar Afghanistan. JAMA, 292(5), 575 - 584. doi: 10.1001/ jama.292.5.575.

Centers for Disease Control and Prevention, 1999. A mental health assessment in Kosovo. Available at: https://scholar.google.com/scholar lookup?title $=\mathrm{A}+$ mental + health + assessment $+\mathrm{in}+$ Kosovo.\&publication year $=1999 \&$ [Accessed: 23 May 2019].

Giulianotti, R. and Armstrong, G., 2011. Sport, the Military and Peacemaking: history and possibilities. Third World Quarterly, 32(3), 379-394.

Iancheva,T., Domuschieva-Rogleva, G., Kuleva,M., 2018. Sensation seeking and stress coping strategies of participants in military missions in Afghanistan and Antarctic Expeditions, Journal of Applied Sport Sceinces, 1, 53-63, doi: 10.37393/jass.2018.01.7

Kabul Moncho Torres, 2019. This Kabul sports complex doubled up as execution arena during Taliban rule, www.efe.com. Available at: https://www.efe.com/efe/english/destacada/this-kabul-sports-complexdoubled-up-as-execution-arena-during-taliban-rule/50000261-4076930 [Accessed: 1 October 2019].

Kaminer, D. et al., 2001.The Truth and Reconciliation Commission in South Africa: relation to psychiatric status and forgiveness among survivors of human rights abuses. The British Journal of Psychiatry, 178(4), 373 - 377. doi: 10.1192/bjp.178.4.373.

Kashdan, T. B., Morina, N. and Priebe, S., 2009. Post-traumatic stress disorder, social anxiety disorder, and depression in survivors of the Kosovo War: Experiential avoidance as a contributor to distress and quality of life. Journal of Anxiety Disorders, 23(2), 185 - 196. doi: 10.1016/j.janxdis.2008.06.006.

Live Cricket Scores \& News - ICC T20 World Cup 2020 (no date). Available at: https://www.t20worldcup.com/ [Accessed: 1 November 2019].

McAfee, B., 1997. 'Instead of Medicine': Report of the Bosnian Mental Health Pilot Project. Refugee Action.

Qazi Abdullah, 2018. 'Afghan Sports History', Afghanistan Online, 19 March. Available at: https://www.afghan-web.com/sports/afghan-sportshistory/ [Accessed: 1 October 2019].

Summerfield, D., 2002. 'Effects of war: moral knowledge, revenge, reconciliation, and medicalised concepts of "recovery", BMJ : British Medical Journal, 325(7372), 1105 - 1107.

Toohey, K. and Taylor, T., 2006. "'Here be dragons, here be savages, here be bad plumbing": Australian media representations of sport and terrorism', Sport in Society, 9(1), 71 - 93. 
Turton, D., 2002. War and Ethnicity: Global Connections and Local Violence. Boydell \& Brewer Ltd.

Vladova, I., 2018. Multikulturalizam. Olimpizam. Obrazovanie. Sofia: NSA-Press. [in Bulgarian]

Woodside, D., Santa Barbara, J. and Benner, D. G., 1999. Psychological trauma and social healing in Croatia. Medicine, Conflict, and Survival, 15(4), 355-367; discussion 391-393. doi: 10.1080/13623699908409477.

\section{Ivanka Martinova}

https://orcid.org/0000-0002-0604-7817

CPE "Terra" at Inovationtech Ltd

Sofia, Bulgaria

E-mail: martinova.ivanka@gmail.com

Muammer Aydin

National Sports Academy "Vassil Levski"

Sofia, Bulgaria 